\title{
Energy Saving in Construction by Wide Application of High-Quality Insulation Based on Basalt Fibers
}

\author{
Vyacheslav Kremnev ${ }^{1}$, Boris Basok ${ }^{1}$, Andriy Timoshchenko', Sergei Tymchyshyn² \\ ${ }^{1}$ Institute of Engineering Thermophysics of the National Academy of Sciences of Ukraine, Kiev, Ukraine \\ ${ }^{2}$ LLC CE “Chernivtsi Plant of Heat-Insulating Materials”, Chernivtsi, Ukraine \\ Email: a_timoshchenko@ukr.net
}

How to cite this paper: Kremnev, V., Basok, B., Timoshchenko, A. and Tymchyshyn, S. (2018) Energy Saving in Construction by Wide Application of HighQuality Insulation Based on Basalt Fibers. Journal of Modern Physics, 9, 1724-1734. https://doi.org/10.4236/jmp.2018.99108

Received: May 8, 2018

Accepted: July 29, 2018

Published: August 1, 2018

Copyright (c) 2018 by authors and Scientific Research Publishing Inc. This work is licensed under the Creative Commons Attribution International License (CC BY 4.0).

http://creativecommons.org/licenses/by/4.0/

\begin{abstract}
The influence of modern heat insulation materials on the ecological compatibility and fire resistance of residential and public buildings is considered. The nomenclature of fibrous heat insulation materials from basic rocks of volcanic origin is described. For basalt super thin fibers (BSTF), the production technology is described. The factors negatively influencing the engineering-andeconomical performance of the duplex technology of production of the BSTF are analyzed. The engineering-and-economical performance of innovative enterprises for the production of basalt heat insulation and measures for its use in construction are given.
\end{abstract}

\section{Keywords}

Basalt Fiber, Ecological Materials, Heat Insulation, Energy Efficiency, Heat Technological Processes

\section{Introduction}

Contemporary trends in construction are such that the requirements to heat consumption for residential and public buildings are getting tougher from year to year ref. [1]. The international community agrees that energy-efficient buildings should not exceed the heat consumption of $70 \mathrm{~kW} \cdot \mathrm{h}$ per square meter per year. However, today in Ukraine, most of the buildings in which there are heating systems do not meet the modern requirements for heat-retaining properties. This situation has developed historically, because for long-time prices for fuel and energy resources have been artificially understated in comparison with the world prices ref. [2]. Consequently, under such conditions, measures aimed at 
energy saving in construction did not have economic substantiation because the growth of capital expenditures due to the increase of heat-retaining properties of buildings did not formally result in significant savings in heating costs. However, attempts were made to introduce energy-saving measures in construction. For example, within the framework of prefabricated concrete technology, specialized three-layer concrete panels were constructed that had two outer layers of heavy concrete and a cavity intermediate, which was filled with mineral wool insulation under the conditions of a prefabricated reinforced concrete plant. Such a concrete panel was quite energy-efficient and quite fire-safe. In particular, it was made from such panels that the external walling constructions of the four buildings of the Department of heat and mass transfer processes and equipment of the Institute of Engineering Thermophysics of the National Academy of Sciences of Ukraine, built in the 70's of last century. These buildings are relatively energy-efficient. At present, the technology of precast concrete is almost not used in the construction. It was superseded by the technology of monolithic construction, on which the bearing frame of the building is executed from solid monolithic reinforced concrete, and external fencing wall constructions-mainly from brick. Unfortunately, the release of three-layer reinforced concrete panels is accordingly discontinued. With monolithic construction, modern normative heatretaining properties of structures are achieved by arranging an external heatinsulating layer. Recently, regulatory requirements for heat-retaining properties of buildings have been significantly increased (Table 1).

In these conditions, existing buildings are thermo-modernized (external surfaces are insulated), and in the new construction, the insulation layers are foreseen at the design stage.

But in our view, these processes are of a spontaneous nature and are accompanied by a significant reduction in environmental friendliness and, worse, the fire safety of structures.

Table 1. Minimum permissible values of resistance to heat transfer.

\begin{tabular}{|c|c|c|c|}
\hline \multirow{2}{*}{$\begin{array}{l}\text { Number } \\
\text { in order }\end{array}$} & \multirow{2}{*}{ Item name } & \multicolumn{2}{|c|}{$\begin{array}{l}\text { Resistance to heat transfer construction, } \\
[\text { (square meter } \cdot \mathrm{C}) / \mathrm{W}]\end{array}$} \\
\hline & & $\begin{array}{l}\text { R0 required, } \\
\text { ref. [3], Table } 1(\mathrm{a})^{*}\end{array}$ & $\begin{array}{l}\text { Rq } \min , \\
\text { ref. [4], Table } 1\end{array}$ \\
\hline \multirow[t]{3}{*}{1} & Residential buildings & & \\
\hline & - walls & 1.6 & 3.3 \\
\hline & $\begin{aligned}- & \text { attic constructions } \\
& (4000 \text { [degrees } \cdot \text { day] })\end{aligned}$ & 2.2 & 4.95 \\
\hline \multirow[t]{3}{*}{2} & $\begin{array}{l}\text { Administrative and } \\
\text { household buildings }\end{array}$ & & \\
\hline & - walls & 1.4 & 3.3 \\
\hline & $\begin{aligned}- & \text { attic constructions } \\
& (4000 \text { [degrees.day] })\end{aligned}$ & 2.0 & 4.95 \\
\hline
\end{tabular}




\section{Qualitative Evaluation of Proposals in the Market of Heat Insulation}

Most of the thermal insulation materials are completely synthetic, or contain in their composition binders of synthetic origin. The location of synthetic insulating materials and materials on synthetic binders inside the wall constructions, or on the interior surfaces of the enclosing structures, is prohibited by sanitary-hygienic and fire regulations. Such sanitary-hygienic requirements are related to the possibility of diffusion of substances harmful to humans (allergens) at the temperature conditions that occur in residentials. As for the fire protection requirements, even the removal of the insulation layer outside is not effective and leads to a significant reduction in fire resistance of structures, especially manystoried buildings. It is through thermal insulation materials the fires take catastrophic character and are accompanied by death of people, primarily because of poisoning with gaseous substances coming from heat-insulating materials, even if they are not burned, but only heated. In this case, for the poisoning of people with gases, it is sufficient to have only synthetic binders in the composition of heat-insulating materials. In recent times, cases of powerful fires in new manystoried buildings have become more frequent. Through natural draught, the flame quickly spread along the facades through a layer of thermal insulation through the entire height of the building. In addition, it should be borne in mind that the internal space of the heat insulation layer is $95 \%-99 \%$ composed of air, and the rest composed of the fibers, that is, in the volume of the heat insulation layer, oxygen is constantly present in an amount sufficient to burn the synthetic binder and poison people with gases.

Such fires occurred in Grozny (Russia) ref. [5], Kiev (Ukraine) ref. [6] and other cities. The last powerful fire under the scenario described was recently held in London (UK) ref. [7]. A few years ago, the fire completely destroyed the main assembly conveyor of KAMAZ PTC (Russia) several kilometers long ref. [8]. The main factor of the catastrophic fire scenario was the thermal insulation layer of the roofing, which was made of foam plastic.

In our opinion regulatory measures are needed from the state aimed at the fact that technical solutions for heat insulation of facilities should not cause a decrease in their fire resistance, at least if it concerns residential or other facilities with people staying.

\section{Effective Heat Insulation Materials from Basic Rocks of Volcanic Origin}

At the same time, heat insulation materials are capable, when used in buildings, not only not to reduce their fire resistance, but, on the contrary, significantly increase their fire resistance. It is to such materials that the heat insulation based on staple basalt fibers belongs.

The raw material for the production of basalt fibers is the basic rocks of magmatic origin-basalts, diabases, andesites and the like. Today, products from these 
rocks are called basalt.

With the help of modern innovative technologies, from basalts produce fibers that are thinner than human hair and have unique useful qualities. These fibers are the primary form of commercial products and on its basis "soft" and "hard" heat insulating materials are produced.

Depending on the diameter, the staple basaltic fibers are divided into coarse (more than $20 \mu \mathrm{m}$ ), thin (from 4 to $20 \mu \mathrm{m}$ ), super-thin (from 1 to $3 \mu \mathrm{m}$ ), ultrathin $(0.5$ to $1 \mu \mathrm{m})$, microthin (less than $0.5 \mu \mathrm{m})$. The diameter of elementary fibers significantly affects their properties-active surface, strength, flexibility, density, elasticity, coefficient of heat conductivity, etc., and thereby determines areas of their scope of use. So, micro- and ultrathin fibers are used in the production of heat-resistant paper-like materials (particularly in aircraft building), in the production of multi-layer heat- and electrical insulation, are used in a number of special technologies. Thin fibers are used in filters and composite materials, the coarse fibers are used for reinforcing concrete products ref. [9].

A promising basis for heat insulation materials and products are super-thin basalt fibers (BSTF). "Soft" heat insulation based on basaltic superthin fibers is a nonwoven stitched material in the form of the canvas, which consists of a set of staple basalt glass fibers with a length of 10 to $100 \mathrm{~mm}$. In addition to "soft" materials on this basis, also "hard" products are produced in the form of slabs of different thickness and rigidity (from cardboards 5 - $20 \mathrm{~mm}$ thick to slabs 30 $100 \mathrm{~mm}$ thick). As a binder they use bentonite clay.

In the field of developing technologies for the production of basalt fibers, materials and products based on them, as well as equipment for the hardware design of these technologies, the USSR took the leading place in the world, and the main role was played by scientists and industrialists of the Ukrainian SSR, in particular, the Institute for Material Science Problems of the Ukrainian SSR Academy of Sciences, Research Institute of fiberglass and fiberglass, etc. One of the reasons that it is Ukrainian science and industry that created this elite product it is the unique properties of Ukrainian basalts. These basalts are extremely promising for the production of super-thin fibers because the temperature range of their melt, at which stretching of the super-thin thread without its breakage is possible, is much higher than the similar index of basalts from other countries. That is, Ukrainian basalts are extremely valuable for the organization of production of super-thin fibers. The first industrial enterprises were created around Kiev (Ukraine).

Heat insulation products based on BSTF have practically no alternative in such industries as: energy (thermal, nuclear) shipbuilding and aircraft construction; wide selection of modern domestic heating boilers of low power; specialized systems in the construction, aimed at increasing the fire resistance of structures (cabins and elevator shafts, passive fire protection systems). Thermophysical properties, durability, resistance to low and high temperatures, vibrations, environmental friendliness and fire resistance, heat insulation products based on BSTF significantly exceed analogues. On the way of expanding their 
application is a high cost, in which part of the energy carriers is more than $80 \%$. Thus, the cost of production depends mainly on the economic efficiency of the heat-technological processes.

\section{Duplex Technology for Production of Staple Super-Thin Basalt Fibers. Ways and Potentials of Intensification}

BSTF is obtained as follows. The raw material is the basalt chippings of fractions of $5-20 \mathrm{~mm}$, which is mined in quarries. Basalt chippings is dosed in the basalt furnace, the furnace heated by burners on natural gas. With the help of furnaces, the following technological tasks are solved: melting of basalt chippings, which ensures their transition from the solid state to the liquid, and also the homogenization of the melt, which consists in removing microcrystals from the melt and converting the melt into an amorphous glassy liquid. This is necessary in order to avoid the fragility of the fibers, which in the presence of microcrystals appear in the subsequent stages of processing. So the homogenized amorphous glassy liquid passes gravity into the so-called feeder device, which is a ceramic container with a perforated bottom (the so-called spinneret), which is made of platinum-rhodium or special refractory alloys. To prevent the cooling of the glass melt, the spinneret is heated by an electric current. The melt streams are forcibly removed through the spinneret into the environment. Thus, due to cooling in air, so-called solid continuous primary filaments are formed in the form of cylinders with a diameter from 150 to $250 \mu \mathrm{m}$. Primary filaments are routed to the area of action of a flat high-temperature jet of natural gas combustion products, which has a speed of about $300 \mathrm{~m} / \mathrm{s}$. When the ensemble of primary filaments interacts with the high-temperature jet, there is a repeated melting and bloating to super-thin fibers that are deposited from the gas stream on the screen filter. A canvas of staple super-thin fibers is formed on the filter. Canvas is continuously or periodically removed from the filter. The basalt raw material undergoes melting two times, so the described multi-stage technology for obtaining super-thin fibers is called "duplex technology".

\section{Features of Duplex Technology, Which Negatively Affect the Engineering-and-Economical Performance of Production}

Integral negative indicator that interferes with the wide distribution of highquality heat insulation is its high prime cost. The high prime cost consists of a combination of costs, some of which can be considered objectively inherent in technology and such that it has no prospects for a significant reduction, and costs that can be reduced through intensification based on the introduction of innovative technical solutions for the technology and equipment.

The objective costs for the production of basalt fiber by duplex technology are the following.

Expenses for expert labor. The operators of the technological plant manually remove breakage of coarse fibers with the help of a metal device. Operators ma- 
nually draw out the fiber from the "bulb" and direct it into the drawing out rollers. This work requires special attention, speed of response, high sensory sensitivity, exceptional technical safety in servicing the equipment of the technological plant. It should be noted that these duties are performed in conditions of high-power heat radiation fluxes from the spinnerets that have a temperature > $1300^{\circ} \mathrm{C}$, high dust content of air, noise and vibrations. All this allows us to regard operators as workers' elite, and the working conditions are extremely difficult. It can be predicted that in the future the duties of operators will not change significantly. It is hardly possible to replace them with robots.

The cost of electrical energy, which is supplied to the spinneret. They should be considered justified, since attempts to replace electricity with other energy carriers (natural gas) are not advisable because of the need for a very fine melt temperature control to ensure the ductile state that is necessary for the stable drawing out of coarse fibers.

Expenses for limited productivity of the spinneret. The high temperature level of the process of formation of coarse fibers does not allow many times to increase its productivity, using the traditional method for manufacturing of the glass fibers-increasing the geometric dimensions of the spinnerets and, accordingly, the number of fibers produced. Actions that in the adjacent industry lead to a multiple increase in the productivity of the coarse fiber production unit (2 6 times) in the case of duplex technology are not applied due to the impossibility of organizing a long stable process of forming and drawing out fibers on the spinneret. One of the main reasons that causes the instability of the formation of coarse fibers is the creep phenomenon of the spinneret material. Thus, it is thermodynamically possible to reduce the specific energy consumption per unit mass of basalt fibrous materials, but this is technologically limited to the existing level of material science development, which causes over-expenditure of energy resources. In addition, spinnerets require periodic replacement due to destruction, and the costs of replacing them are beyond the competence of thermophysicists and constitute a task for materials science specialists.

To the expenditure that can be significantly reduced through the use of innovative technical solutions include the following:

- For raw materials (basalt chippings);

- On structural materials (ceramic materials of furnaces, materials of spinnerets);

- On the supply of compressed air to the burners (furnaces and blowing chambers);

- On water for cooling,

- For natural gas.

IET NASU together with IG NASU and LLC CE "Chernivtsi plant of heatinsulating materials" developed a new energy-saving duplex technology for the production of BSTF and the technological plant for its hardware implementation, which enabled the first stage of technology (production of the basalt glass) to reduce the specific consumption of natural gas in 4 times, at the second stage 
(melting and blowing of the coarse basalt fibers) - 1.2 times. In relation to the final product-"soft" heat insulation-the specific consumption of natural gas has been reduced by a factor of 1.5. The prime cost of finished products is reduced by 1.2 times in relation to products manufactured in the technological plant of the first generation.

A new technology and equipment for the production of the slabs, in which BSTF act as raw material, has also been developed. In this technology, the specific consumption of natural gas per cubic meter of slabs is reduced by $1.3-1.5$ times.

Conducted fundamental researches and carried out with the application of their results the developments provide the technical and technological basis for mass production of "soft" and "hard" heat insulation products based on basalt fibers. But for the wide application of such heat insulation in the construction and reconstruction of buildings, it is equally important to use the optimal technical solutions for the arrangement of the basalt heat insulation layer in the conditions of the construction site with the obligatory provision of its mechanical and hydrotechnical protection for the entire service life.

\section{Engineering-and-Economical Performance of Innovative Enterprises for the Production of Basalt Heat Insulation and Measures for Its Use in Construction}

The practical solution of the problem of wide introduction in the construction of basalt insulation, which is very important, requires a systematic approach and the convergence of various fields of science, technology and industry with mandatory regulatory influence on the part of the state. It is necessary to coordinate the efforts of heat engineering, materials science specialists, construction heat engineers, architects, economists and the like. The feasibility study must necessarily cover the entire "chain" from the extraction of basalt crushed stone into the operation of finished heat-insulated structures, where the final result is achieved to save energy for heating. In the course of such a feasibility study it will be possible to optimize the entire process aimed at the final result-energy saving. So, for example, the rise in price of "hard" heat insulating materials in comparison with "soft" materials can be compensated by a reduction in the cost of work on the installation of heat insulation in building conditions, etc. It is important to note that Ukraine has significant advantages in organizing the production of basalt heat insulation due to the fact that the local basalts are $\mathrm{ex}^{-}$ ceptionally suitable for the production of fibers due to the ability of their melt to be in the ductile state in the wide temperature range. This is extremely important for the stable technological process of drawing out basalt fibers.

The new technologies and equipment allow the creation of innovative standard enterprises in a modular manner with the ability to regulate their productivity in accordance with local demand. Enterprises should be created with the understanding that it is much more economical to transport basalt raw materials with a density of $1600 \mathrm{~kg}$ per cubic meter than heat insulation with a density of 40 - 
$50 \mathrm{~kg}$ per cubic meter. Complete developments already made allow to achieve the cost of basalt heat insulation at such enterprises-due to a significant reduction in energy consumption-at a level that does not exceed the cost of flammable heat insulation is widely used today. Below are the planned technical and economic indicators of the second generation workshops for the production of basalt heat insulation (Table 2), the specific indicators of the cost of heat insulation (Table 3 ) and the current information for assessing the economic efficiency of measures for thermomodernization of the enclosing structures of residential and administrative buildings (Table 4 ).

\section{Economic-Organizing Systemic Measures That Promote the Production and Wide Application of Heat Insulation Based on Basalt Fibers}

In order to reduce the cost of energy consumption by significantly increasing heat-retaining properties with the use of long-term, ecological heat insulation,

Table 2. Capital costs for the creation of workshops for the production of basalt heat insulation.

\begin{tabular}{|c|c|c|c|}
\hline $\begin{array}{l}\text { Number } \\
\text { in order }\end{array}$ & Item name & Unit of measurement & Value \\
\hline \multirow[t]{4}{*}{1} & $\begin{array}{l}\text { Workshop for production heat } \\
\text { insulation-sew-knit mats without facing МТПБа } \\
\text { (ТУ У В.2.7-23.9-00292818-001: 2012) ref. [10] }\end{array}$ & [thousand dollars US] & 860 \\
\hline & including: & & \\
\hline & building of workshop & [thousand dollars US] & 270 \\
\hline & $\begin{array}{l}\text { technological equipment (including installation, } \\
\text { starting-up and adjustment, personnel training) }\end{array}$ & [thousand dollars US] & 590 \\
\hline 1.1 & $\begin{array}{l}\text { Annual capacity of the workshop } \\
\text { for finished products }\end{array}$ & [thousand cubic meters] & to 30.0 \\
\hline \multirow[t]{2}{*}{1.2} & Operating mode of equipment & [hours per day] & 16 \\
\hline & & [hours per year] & 4800 \\
\hline 1.3 & Service life of equipment and structures & [years] & 20 \\
\hline \multirow[t]{4}{*}{2} & $\begin{array}{l}\text { Workshop for production } \\
\text { heat-insulating-slabs ПМТБ-2 (ТУ У } \\
\text { B.2.7-23.9-00292818-001:2012) ref. [10] }\end{array}$ & [thousand dollars US] & 990 \\
\hline & including: & & \\
\hline & building of workshop & [thousand dollars US] & 270 \\
\hline & $\begin{array}{l}\text { technological equipment (including installation, } \\
\text { starting-up and adjustment, personnel training) }\end{array}$ & [thousand dollars US] & 720 \\
\hline 2.1 & $\begin{array}{l}\text { Annual capacity of the workshop } \\
\text { for finished products }\end{array}$ & [thousand cubic meters] & to 5.7 \\
\hline \multirow[t]{2}{*}{2.2} & Operating mode of equipment & [hours per day] & 24 \\
\hline & & [hours per year] & 8040 \\
\hline 2.3 & Service life of equipment and structures & [years] & 20 \\
\hline
\end{tabular}


Table 3. Planned specific indicators of the prime cost of heat insulation products-variable costs.

\begin{tabular}{|c|c|c|c|}
\hline $\begin{array}{l}\text { Number } \\
\text { in order }\end{array}$ & Item name & Unit of measurement & Value \\
\hline 1 & $\begin{array}{l}\text { Sew-knit mats without facing МТПБа } \\
\text { (ТУ У В.2.7-23.9-00292818-001: 2012) ref. [10] }\end{array}$ & & \\
\hline 1.1 & Volume of finished products (annual) & thousand cubic meters & to 30.0 \\
\hline 1.2 & Consumption of natural gas (annual) & million cubic meters & to 2.6 \\
\hline 1.3 & Electricity consumption (annual) & million $\mathrm{kW} \cdot \mathrm{h}$ & to 4.5 \\
\hline \multirow[t]{7}{*}{1.4} & $\begin{array}{l}\text { Prime cost one cubic meter heat insulation } \\
\text { including: }\end{array}$ & dollars US & 48.0 \\
\hline & - natural gas & dollars US & 27.9 \\
\hline & - electricity & dollars US & 7.2 \\
\hline & - wages fund & dollars US & 10.2 \\
\hline & - raw materials & dollars US & 0.6 \\
\hline & - amortization costs & dollars US & 0.1 \\
\hline & - current repairs & dollars US & 2.0 \\
\hline 2 & $\begin{array}{l}\text { Soft heat-insulating slabs ПМТБ-2 } \\
\text { (ТУ У В.2.7-23.9-00292818-001: 2012) ref. [10] }\end{array}$ & & \\
\hline 2.1 & Volume of finished products (annual) & thousand cubic meters & to 5.7 \\
\hline 2.2 & Consumption of natural gas (annual) & million cubic meters & to 0.12 \\
\hline 2.3 & Electricity consumption (annual) & million $\mathrm{kW} \cdot \mathrm{h}$ & to 0.5 \\
\hline \multirow[t]{6}{*}{2.4} & $\begin{array}{l}\text { Prime cost one cubic meter heat insulation } \\
\text { including: }\end{array}$ & dollars US & 259.8 \\
\hline & - natural gas & dollars US & 135.8 \\
\hline & - electricity & dollars US & 23.5 \\
\hline & - wages fund & dollars US & 31.4 \\
\hline & - raw materials & dollars US & 52.3 \\
\hline & - amortization costs & dollars US & 16.8 \\
\hline
\end{tabular}

which simultaneously increases the fire resistance of structures, the following economic-organizing system measures are proposed that will stimulate both the production of such products and its use in construction.

Measures to stimulate production, for legal entities wishing to create new production capacities for the production of basalt heat insulation, are proposed:

- Facilitate long-term loans with low interest rates;

- Facilitate the receipt of land for the construction of production capacities in the regions;

- To apply forms of interaction of entrepreneurs with the state on the basis of legislation on state-private partnership (this form plays an important role in the development of modern China); 
Table 4. Up-to-date information for assessing the economic efficiency of actions for the thermomodernization of constructions of residential and administrative buildings.

\begin{tabular}{|c|c|c|c|c|}
\hline \multirow[b]{2}{*}{$\begin{array}{l}\text { Number } \\
\text { in order }\end{array}$} & \multirow[b]{2}{*}{ Item name } & \multirow[b]{2}{*}{$\begin{array}{c}\text { Unit of } \\
\text { measurement }\end{array}$} & \multicolumn{2}{|r|}{ Value } \\
\hline & & & walls & $\begin{array}{l}\text { attic } \\
\text { constructions } \\
\quad(4000 \\
\text { degrees.day })\end{array}$ \\
\hline 1 & $\begin{array}{l}\text { The minimum value of the thermal resistance, } \\
\text { which must be achieved by additional } \\
\text { heat insulation of the construction }\end{array}$ & $\begin{array}{c}\text { (square } \\
\text { meter.C)/W }\end{array}$ & 1.7 & 2.75 \\
\hline 2 & $\begin{array}{l}\text { Reduction of the average heat flow } \\
\text { density after thermomodernization }\end{array}$ & $\begin{array}{l}\text { W/square } \\
\text { meter }\end{array}$ & 6.2 & 4.8 \\
\hline 3 & \multicolumn{4}{|c|}{ Sew-knit mats without facing МТПБа (ТУ у в.2.7-23.9-00292818-001: 2012) ref. [10] } \\
\hline 3.1 & The required thickness of the heat insulation layer & meter & 0.05 & 0.08 \\
\hline 3.2 & Cost of heat insulation materials & $\begin{array}{l}\text { dollars } \\
\text { US/square } \\
\text { meter }\end{array}$ & 2.4 & 4.0 \\
\hline 4 & \multicolumn{4}{|c|}{ Soft heat-insulating slabs ПМТБ-2 (ТУ У В.2.7-23.9-00292818-001: 2012) ref. [10] } \\
\hline 4.1 & The required thickness of the heat insulation layer & meter & 0.065 & 0.11 \\
\hline 4.2 & Cost of heat insulation materials & $\begin{array}{l}\text { dollars } \\
\text { US/square } \\
\text { meter }\end{array}$ & 24.9 & 41.6 \\
\hline
\end{tabular}

- To create such a subindustry of heat insulation production in the form of franchising, which will allow to maintain the constant connection of scientific institutions with enterprises by producers and quickly transfer practical experience and innovations.

\section{Measures to stimulate production:}

- With the aim of promoting broad use in construction and stimulating demand from users of the housing, it is proposed at the stage of state expertise of projects for buildings in which ecological heat insulation materials are used that do not contain organic substances and increase the fire resistance of structures, establish high safety and quality indicators;

- Private developers who use such heat insulation materials provide targeted multi-year soft loans.

\section{Conclusions}

Regulatory measures are needed from the state aimed at the fact that technical solutions for heat insulation of facilities should not cause a decrease in their fire resistance, at least if it concerns residential or other facilities with people staying.

A promising basis for heat insulation materials and products is super-thin basalt fiber (BSTF).

On the way of expanding their application is a high cost, in which part of the energy carriers is more than $80 \%$. Thus, the cost of production depends mainly on the economic efficiency of the heat-technological processes. 
For the wide application of such heat insulation in the construction and reconstruction of buildings, it is equally important to use the optimal technical solutions for the arrangement of the basalt heat insulation layer in the conditions of the construction site with the obligatory provision of its mechanical and hydrotechnical protection for the entire service life.

Engineering-and-economical performance of innovative enterprises for the production of basalt heat insulation and measures for its use in construction are presented.

\section{Conflicts of Interest}

The authors declare no conflicts of interest regarding the publication of this paper.

\section{References}

[1] Bogoslovskiy, V.N. and Skanavi, A.N. (1991) Otopleniye: Ucheb. dlya vuzov. [Heating: Educational for Universities]. Stroyizdat, 735 s. (In Russian)

[2] https://www.calc.ru/dinamika-Gas.html

[3] SNiP II-3-79* Stroitel'naya teplotekhnika [Construction Heat Engineering]. (s izm. No. 4 [With Changes \#4]). (In Russian)

[4] DBN V.2.6-31-2006 Teplova izolyatsiya budivel' [Thermal Insulation of Buildings] (zi zminoyu [With Changes]). (In Ukraine)

[5] https://life.ru/t/новости/112431

[6] http://www.novoteka.ru/seventexp/6950507/15263358

[7] http://www.bbc.com/russian/news-40366259

[8] http://fire-truck.ru/encyclopedia/pozhar-na-kamaze-14-aprelya-1993-goda-faktyi-ikommentarii.html

[9] Dzhigiris, D.D. and Makhova, M.F. (2002) Osnovy proizvodstva bazal'tovykh volokon i izdeliy [Basics of Production of Basalt Fibers and Articles]. Teploenergetik [Thermal Power Engineer], Moscow, 416 p. (In Russian)

[10] http://rotys.com 